\title{
Cytology of the outer penis epithelium of Buccinum undatum (L.) from the arctic region - an observation of the imposex phenomenon
}

\author{
M. Brick \& M. Bolte \\ Institut für Spezielle Zoologie und Vergleichende Embryologie der Universität Münster; \\ Hüfferstraße 1, 48149 Münster, Federal Republic of Germany
}

\begin{abstract}
TBT (tributyltin)-induced imposex is observed in female Buccinum undatum from the arctic region. The fine structure of the male penis epithelium was investigated and the results were compared between specimens from non-polluted (Spitsbergen, Norway) and highly-polluted (Brittany, France) areas. Differences in the arrangement and structure of the apical microvilli-border, the intercellular spaces, RER and SER content, as well as a high rate of parasitism in the tissue of individuals from Brittany can be detected between the species of both areas. The results indicate a higher degree of pathological changes in the penis epithelial cells of individuals from TBT-polluted areas than in those from Spitsbergen.
\end{abstract}

\section{INTRODUCTION}

Imposex is a widespread phenomenon of penis and/or vas deferens development in the female of several species of prosobranch gastropods. It has been investigated on a large scale in the last few years with regard to increasing TBT (tributyltin) pollution resulting from the use of antifouling paints (Bright \& Ellis, 1990; Fioroni et al., 1991; Gibbs et al., 1988; Oehlmann et al., 1992; Short et al., 1989; Stroben et al., 1992). TBT is also used as a biocide in various formulations. Gibbs et al. (1987) discovered that imposex in Nucella lapillus is already induced by concentrations below $1 \mathrm{ng} \mathrm{l}^{-1}$. In 1984, Kantor described the imposex phenomenon, called pseudohermaphroditism, of Buccinum undatum from the Solowezi islands (White Sea, former USSR). The widespread environmental pollution makes it difficult to get prosobranchs from TBT-free areas. Therefore, specimens from the arctic region were investigated in this study.

In order to obtain information about the epithelial structure of the penis of prosobranchs not affected by TBT, the cell structure of male $B$. undatum from arctic TBT-free water was investigated. The results were compared with those of $B$. undatum collected from Brittany (France), an area with high TBT concentration in the water (Oehlmann et al., 1993b). Information is still lacking in regards to the cytology of penis epithelial cells of TBT-exposed and non-exposed males and females. Some results of ultrastructural cell changes were described for male and imposex-affected females of Hinia and Ocinebrina (Brick \& Deutsch, 1993). 


\section{MATERIALS AND METHODS}

Specimens of $B$. undatum were collected from the Kongsfjorden at Ny Alesund (Spitsbergen/Norway, $78^{\circ} 93 \mathrm{~N} 11^{\circ} 95 \mathrm{E}$ ) in August 1992. Eighteen animals were caught in 3-10 m depth using selfmade traps baited with flesh.

In order to investigate the morphology and for electron microscopy fixation, the snails were narcotized with $7 \% \mathrm{MgCl}_{2}$ in distilled water. After the shell was cracked, the external dimensions were measured and the sex was determined.

The specimens were fixed for scanning electron microscopy (SEM) in $5 \%$ formalin and then preserved in $70 \%$ ethanol. For transmission electron microscopy (TEM), the tissue of the male penis was fixed at $4{ }^{\circ} \mathrm{C}$ overnight in $2 \% \mathrm{OsO}_{4}(\mathrm{pH} 7.2-7.4)$ dissolved in $5 \% \mathrm{~K}_{2} \mathrm{Cr}_{2} \mathrm{O}_{7}$ (Riedel de Haen). After embedding in Spurr's resin (Spurr, 1969), ultrathin sections were stained with $1 \%$ lead citrate and observed with a Siemens electron microscope.

Specimens for SEM were dehydrated via a graded ethanol series, critical point dried and coated with gold for examination with a Hitachi scanning electron microscope S-530.

Water samples from Kongsfjorden were analysed by the Bayrische Landesanstalt für Wasserforschung, Munich (Germany).

Morphometric measurements of the surface/volume - relation (S/V-relation) of mitochondria of the penis epithelium were carried out by using the test point and intersection method (Sitte, 1967) $(\mathrm{n}=15$; number of analysed mitochondria).

\section{RESULTS}

A total of eighteen specimens of arctic Buccinum undatum were investigated. Five individuals were male, eight were female, and five specimens were shown to have been affected by imposex (imposex-stage: $1 a_{t} 1 c_{r} 2 a$ and $3 a_{i}$ Stroben et al, 1992), which was assumed to be induced by TBT (tributyltin) environmental pollution. Figures 1 and 2 document the outgrowth of a small penis behind the right tentacle with the penisduct at the top (Fig. 3). In Figure 4 a more prolonged penis is shown on the top of the mantel epithelium. The vagina is still open and unaffected (Fig. 5).

The following ultrastructural investigations of the male penis epithelium of $B$. undatum, collected from Spitsbergen, were compared with the ultrastructure of $B$. undatum collected from the surroundings of Roscoff (Brittany, France), an area of high TBT pollution.

The outer penis epithelium of male $B$. undatum consists of distinctly prismatic cells with a centrally located, elongated nucleus. In contrast to specimens of Spitsbergen, which contained high amounts of euchromatin (Fig. 6), the nuclei of individuals from Brittany were more rich in heterochromatin (Fig. 7).

Figs 1-2. SEM photograph of imposex-affected $B$. undatum (stage 2a, Spitsbergen). Small penis behind the right tentacle. Abbreviations: Pe, penis; Te, tentacle. Scale bar: $0.55 \mathrm{~mm}$

Fig. 3. Detail of Figure 2. Scale bar: $55 \mu \mathrm{m}$

Fig. 4. SEM photograph of imposex female (stage 3a, Spitsbergen). Penis with penis duct. Scale bar: $0.82 \mathrm{~mm}$

Fig. 5. SEM photograph of the vaginal opening of B. undatum (stage 3a, Spitsbergen). Abbreviations: $A$, anus; Va, vaginal opening. Scale bar: $0.82 \mathrm{~mm}$ 

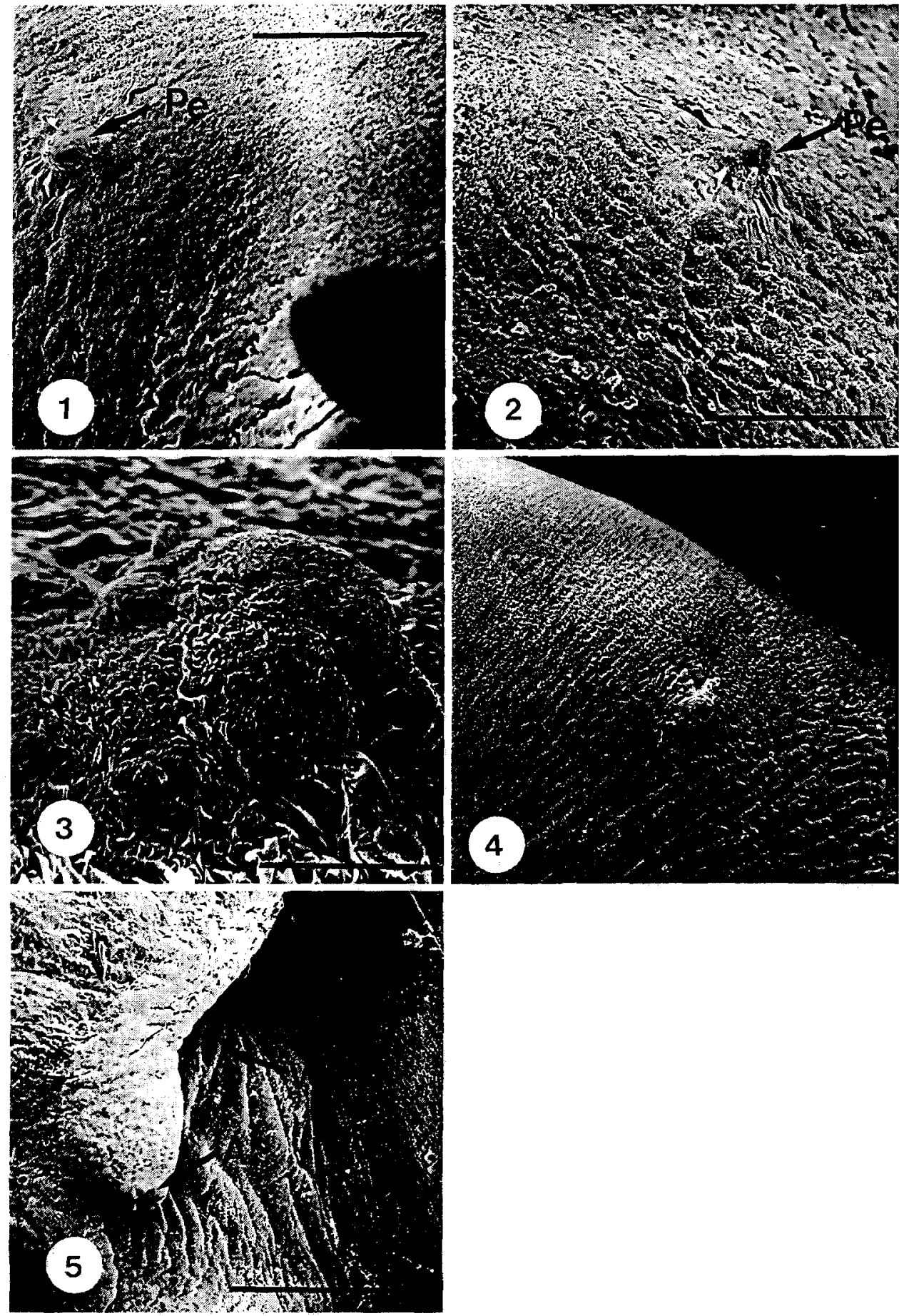
Significant differences could be observed in the arrangement of the apical cell region. While individuals from Spitsbergen have an extremely osmophilic and welldeveloped brushborder of microvilli with a few cilia, specimens from Brittany showed a less dense, non-osmophilic brushborder (Fig. 7). Furthermore, microvilli from specimens of Spitsbergen were often apically inflated (Fig. 8), whereas those of Brittany did not show such extensions.

The lateral region is characterized by distinct membrane interdigitations of the cytoplasmatic membrane along the whole extent of the cell. In specimens from Spitsbergen, two cell types of different cytoplasm were found. The most prominent one consisted of a less electron-dense cytoplasm and the other type had a dark, electron dense cytoplasm with intensive membrane interdigitations (Fig. 9). The epithelial cells of individuals from Brittany consisted only of the first cell type described above.

Intercellular spaces often penetrate the cytoplasm (Fig. 10). They were more frequent and had a larger volume in specimens from Spitsbergen than in those from Brittany. Such spaces are apparent in both the apical and basal regions (Fig. 11) in individuals from Spitsbergen, instead of only appearing in the apical region - as with the specimens from Brittany.

The cells of the specimens from both areas were well-equipped with organelles such as Golgi bodies, ribosomes, endoplasmatic reticulum (ER), mitochondria, pinocytotic vesicles, vacuoles, pigment granules and microfilament material. ER was mostly found in the basal cell region and Golgi bodies were situated in the apical cell region in animals from Spitsbergen. Specimens from Brittany showed a higher number of smooth ER (SER) and they were much more influenced by parasitism than those from Spitsbergen (Fig. 12). Furthermore, we have more frequently detected degenerated cell organelles in the snails from Brittany.

The arrangement and organization of the mitochondria were relatively similar within the individuals of both areas, but morphometric studies have shown a higher S/V-relation in specimens from Spitsbergen $\left(19.7 \mu^{2} / \mu^{3}\right)$ in contrast to specimens from Brittany $\left(15.5 \mu^{2} /\right.$ $\mu \mathrm{m}^{3}$ ).

The analysis of the water gave no indication of TBT-pollution (detection limit $0.1 \mathrm{ng}$ $\operatorname{TBT} 1^{-1}$ ).

\section{DISCUSSION}

The occurrence of imposex-affected females of Buccinum undatum from the arctic region was demonstrated for the first time. Furthermore, a comparison was drawn

Fig. 6. TEM photograph of the male penis epithelium of individuals from Spitsbergen. Note the different cell types. Abbreviations: $\mathrm{Mv}$, microvilli; $\mathrm{Pi}$, pigments; $\mathrm{RER}$, rough endoplasmatic reticulum; GC, Golgi complex; Mi, mitochondrium; N, nucleus; EU, euchromatin. Arrows: membrane interdigitations. Scale bar: $2.4 \mu \mathrm{m}$

Fig 7. Penis epithelium of specimens from Brittany. Note the decreased osmophilic microvilli layer. Abbreviations: Mv, microvilli; Pi, pigments, V, vacuole; EU; euchromatin; HE, heterochromatin. Scale bar: $2.2 \mu \mathrm{m}$

Fig. 8. Apical protuberances of the microvilli brushborder of specimens from Spitsbergen. Scale bar: $1.0 \mu \mathrm{m}$

Fig. 9. Interdigitation (arrows) of different cell types of the penis epithelium of individuals from Spitsbergen. Scale bar: $1.0 \mu \mathrm{m}$ 


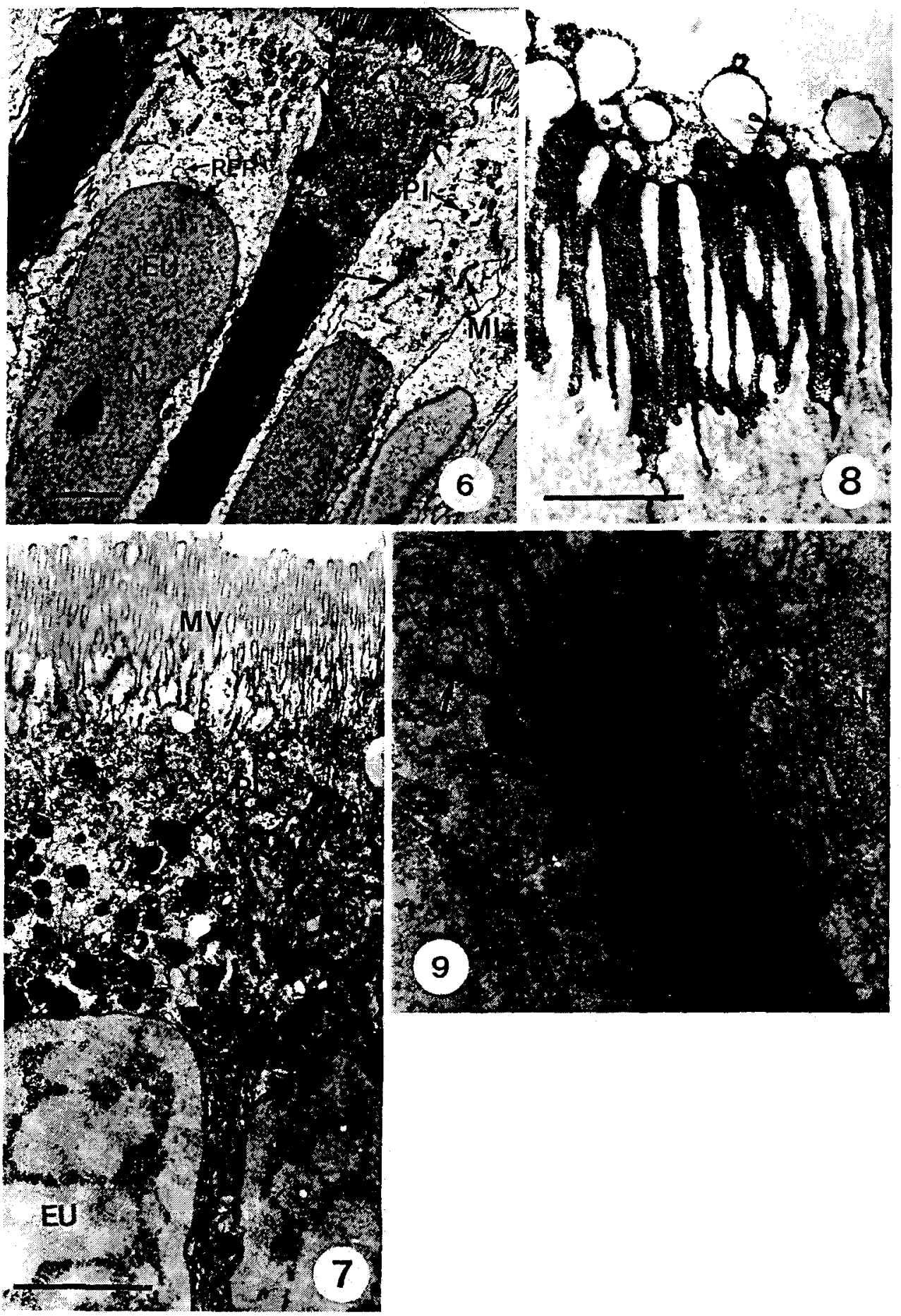


between the cell structure of the outer penis epithelium of specimens from Spitsbergen and those from Brittany. We have investigated individuals from two different areas, one with no TBT water pollution (Spitsbergen), the other with a high TBT water concentration (between 1989 and 1992, 38.6 $\pm 14.6 \mathrm{ng} \mathrm{l^{-1 }}$ TBT, $\mathrm{n}=19$; Oehlmann et al., 1993b).

Although no TBT was found in the water column arround Ny Alesund, we have found that female $B$. undatum are affected by imposex development. Since the sediment accumulates TBT to a high extent (Cardarelli \& Evans 1980; Kalbfuß et al. 1991; Kram et al., 1989; Krone et al., 1989), we suppose that the sediment and probably the TBTaccumulation in the food of $B$. undatum were responsible for penis development in females. It will still be necessary to establish if sediments of the Kongsfjorden are polluted with TBT.

The investigation of the cytology of the outer penis epithelium provided further information about the fitness of these cells in male individuals. The outer penis epithelial cells from $B$. undatum contained many more organelles than were seen in Ocinebrina aciculata, Hinia reticulata and $H$. incrassata, which were also seriously affected by environmental- and especially TBT-pollution (Brick \& Deutsch, 1993). In contrast to specimens from Spitsbergen, the cells of $B$. undatum from Brittany appeared to be more affected by pollutants than the former. They showed a lower number of ribosomes and Golgi bodies. This points to a reduced synthesis activity in these cells. A restricted synthesis has also been demonstrated in $O$. aciculata and in both Hinia species, which were collected from the same region of Brittany (Brick \& Deutsch, 1993). Furthermore, the proliferation of SER, which has been observed in $B$. undatum from Brittany, points to a disproportion between proteins and lipids in the cells (Rez, 1986) and is a symptom of intoxication (Braunbeck et al., 1989).

One of the main differences was the arrangement and shape of the microvilli brushborder. The apical extention of the microvilli in specimens from Spitsbergen is probably induced by a high rate of secretion activity. Such microvilli have also been observed in Littorina littorea (Deutsch \& Brick, 1993).

The high number of intercellular spaces in specimens from Spitsbergen may provide a well-developed transport of substances between these epithelial cells. Because of the higher number of intercellular spaces, the substance transport is obviously more intensive in individuals from Spitsbergen than in those from Brittany. Furthermore, microtubules were found directly in the cytoplasm under the apical brushborder. Vale (1987) has described an intracellular transport function for such microtubules.

In conclusion, it can be stated that epithelial cells of $B$. undatum from Spitsbergen showed a better fitness than those from Brittany. But imposex has been observed in both. in specimens from Brittany (Fioroni et al. 1991) and from Spitsbergen. For further interpretation, it will be necessary to analyse the sediments of this arctic region.

Fig. 10. Intercellular spaces in the apical cell region of individuals from Spitsbergen. Abbreviations: $\mathrm{Mv}$, microvilli; Mi, mitochondrium; IS, intercellular space; GC, Golgi complex. Arrows: microfilament material. Scale bar; $1.0 \mu \mathrm{m}$

Fig. 11. Basal region of the epithelium cells of specimens from Spitsbergen. Abbreviations: IS, intercellular space; N, nucleus; BL, basement membrane; Scale bar: $1.0 \mu \mathrm{m}$

Fig. 12. Detail of the penis cell cytoplasm of individuals from Brittany. Note the degeneration of organelles (arrow). Abbreviations: Ly, lysosome; SER, smooth endoplasmatic reticulum; V, vacuole. 


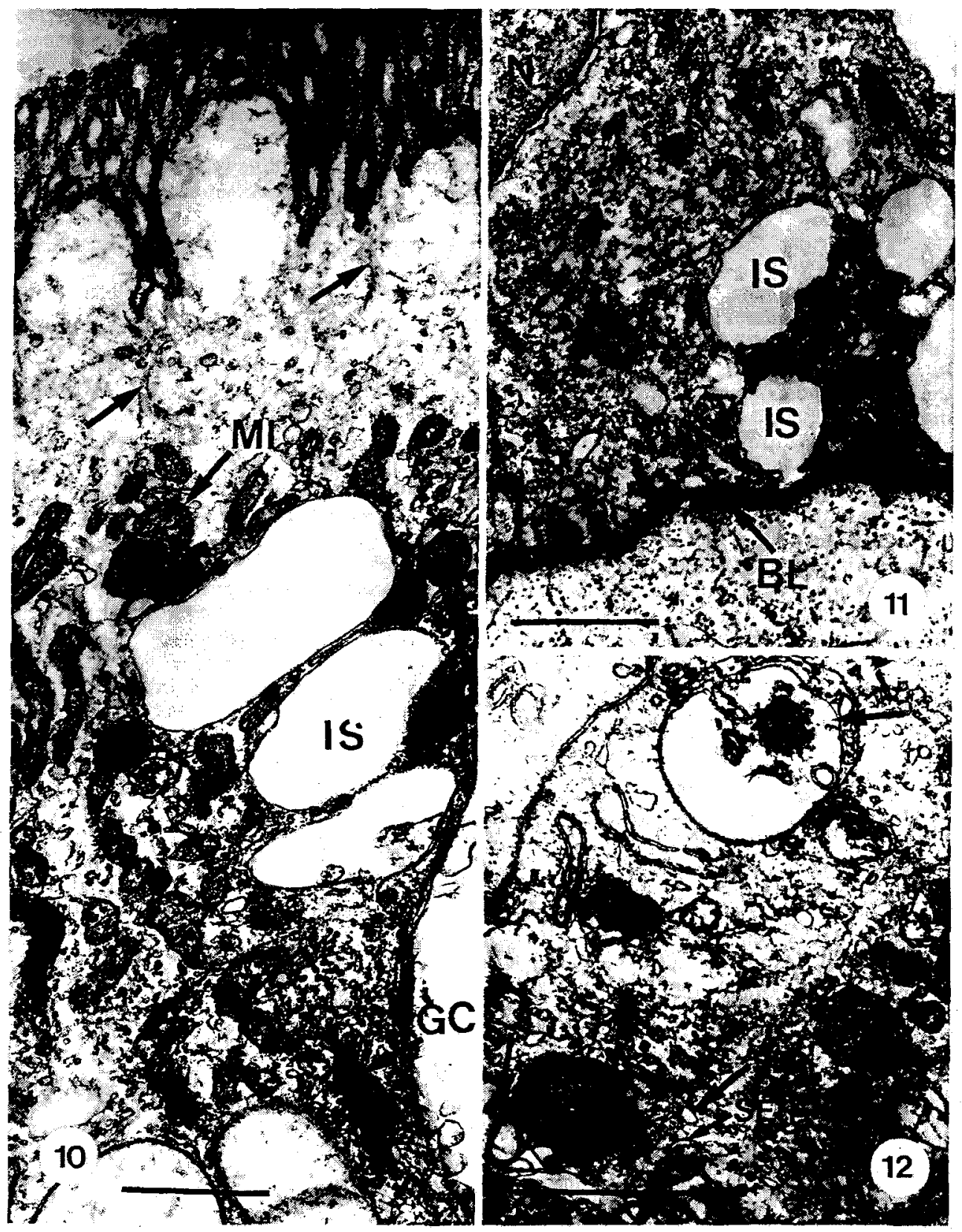


Acknowledgements. We are indebted to the Alfred-Wegener-Institut in Bremerhaven (Germany) for the opportunity to stay at the Koldewey-Station in Ny Alesund during the period of our research and also to the members of the Norsk Polarinstitutt (Norway) for their assistance in collecting the specimens. We are grateful to Dr. W. KalbfuB for analysing the water samples, to Christel Mehlis for her expertise in electron microscopy, to J. Oehlmann and E. Stroben for competent advice and to Dr. G. Wildenburg for the assistance with the English manuscript. The study was supported by the Konrad-Adenauer-Foundation, and is part of the doctoral thesis of Martina Brick.

\section{LITERATURE CITED}

Braunbeck, Th., Storch, V. \& Nagel, R., 1989. Sex-specific reaction of liver ultrastructure in zebra fish (Brachydanio rerio) after prolonged sublethal exposure to 4-nitrophenol. - Aquat. Toxicol. 14, $185-202$.

Brick, M. \& Deutsch, U., 1993. Ultrastructural investigations of the penis epithelia cells of three neogastropods, collected from TBT (tributyltin)-polluted areas. - Aquat. Toxicol. 27, 113-132.

Bright, D. A. \& Ellis, D. V., 1990. A comparative survey of imposex in northeast Pacific neogastropods (Prosobranchia) related to tributyltin contamination, and a choice of a suitable bioindicator. Can. J. Zool. 68, 1915-1924,

Cardarelli, N. F.\& Evans, W., 1980. Chemodynamics and environmental toxicology of controlled release organotin molluscides. In: Controlled release of bioactive materials. Ed. by R. Baker. London, Acad. Press, 357-385.

Deutsch, U. \& Brick, M., 1993. Morphological effects of tributyltin (TBT) in vitro on the genital system of the mesogastropoda Littorina littorea (Prosobranchia). - Helgolander Meeresunters. $47,49-60$.

Fioroni, P., Oehlmann, J. \& Stroben, E., 1991. The pseudohermaphroditism of prosobranchs; morphological aspects. - Zool. Anz. 226, 1-26.

Fioroni, P., Stroben, E. \& Oehlmann, J., 1991. Fréquence et degrể d'expression du pseudohermaphroditisme chez quelques Prosobranches Sténoglosses de la Baie de Morlaix et de la Manche. 1. Situation au printemps de 1988. - Cah. Biol. mar. 32, 281-294.

Gibbs, P. E., Bryan, G. W., Pascoe, P. L. \& Burt, G. R., 1987. The use of the dog-whelk, Nucella lapillus, as an indicator of tributyltin (TBT) contamination. - J. mar, biol. Ass. U.K. 67, 507-523.

Gibbs, P. E., Pascoe, P. L. \& Burt, G. R., 1988. Sex change in the female dog-whelk, Nucella lapillus, induced by tributyltin from antifouling paints. - J. mar. biol. Ass. U.K. 68, 715-731.

KalbfuB, W., Zellner, A., Frey, S. \& Stanner, E., 1991. Gewässergefährdung durch organozinnhaltige Antifoulinganstriche. - Texte UBA 44/91, 1-165.

Kantor, Yu. I., 1984. Pseudohermaphroditism in Buccinum undatum (Gastropoda, Prosobranchia). Zool. Zh. 63, 1256-1258.

Kram, M. L., Stang, P. M. \& Seligman, P. F., 1989. Adsorption and desorption of tributyltin in sediments of San Diego Bay and Pearl Harbor. - Appl. organometal. Chem. 3, 523-536.

Krone, C. A., Brown, D. W., Burrows, D. G., Bogar, R. G., Chan, S.-L. \& Varanasi, U., 1989. A method for analysis of butyltin species and measurement of butyltins in sediment and English sole livers from Puget Sound. - Mar. environ. Res. 27, 1-18.

Oehlmann, J., Stroben, E. \& Fioroni, P., 1992. The rough tingle Ocenebra erinacea (Gastropoda: Muricidae): an exhibitor of imposex in comparison to Nucella lapillus. - Helgoländer Meeresunters. $46,311-328$.

Oehlmann, J., Stroben, E. \& Fioroni, P., 1993 b. Fréquence et degré d'expression du pseudohermaphroditisme chez quelques Prosobranches Sténoglosses des côtes françaises (surtout de la baie de Morlaix et de la Manche). 2. Situation jusqu' au printemps de 1992. - Cah. Biol. mar. 34, $343-362$.

Rez, G., 1986. Electron microscopic approaches to environmental toxicity. - Acta hungarica, 37, $31-45$.

Short, J. W., Rice, S. D., Brodersen, C. C. \& Stickle, W. B., 1989. Occurrence of tri-n-imposex in the North Pacific marine snail Nucella lima in Auke Bay, Alaska. - Mar. Biol. 102, 291-297.

Sitte, H., 1967. Morphometrische Untersuchungen an Zellen. In: Quantitative methods in morphology. Ed. by E. R, Weibel \& H. Elias. Springer, Berlin, 167-198. 
Spurr, A. R. (1969). A low-viscosity epoxy resin embedding medium for electron microscopy. - J. Ultrastruct. Res. 26, 31-43.

Stroben, E., Oehlmann, J. \& Fioroni, P., 1992. The morphological expression of imposex in Hinia reticulata (Gastropoda: Buccinidae). A potential indicator of tributyltin pollution. - Mar. Biol. 113. 625-636.

Stroben, E., Oehlmann, J. \& Fioroni, P., 1992. Hinia reticulata and Nucella lapillus. Comparison of two gastropod tributyltin bioindicators. - Mar. Biol. 114, 289-296.

Vale, R., 1987. Intercellular transport using microtubule-based motors. - A. Rev. Cell Biol. 3 , $347-378$. 